\title{
Pengelolaan Rantai Pasok dan Daya Saing Kelapa Sawit di Aceh
}

D 0 I:10.18196/ agr.1214

\begin{abstract}
Nowadays, supply chain management is vital for palm oil plantations, along with the increases of competitive efforts and equal partnership position between suppliers and processors. The research aimed at mapping supply chain patterns of palm oil plantation, at analyzing performances of palm oil stakeholders, and at analyzing factors influencing performances of stakeholders in the province. The research was conducted using survey method by interviewing and focus group discussion. The results showed that (1) there were 3 supply chains flows from bunches of palm fruit to plants of palm fruit processing; (2) roles of stakeholders in supply chain management determining supply volumes, profits, and value added; and (3)
\end{abstract}

factors influencing performances of stakeholders and competitive advantages were plantation productivity, cost allocation for invesment and operation, capacity of processing plants, and CPO rendemen rate.

Keywords: supply chain, palm oil plantation, competitive advantages.

\section{INTISARI}

Saat ini pengelolaan rantai pasok (SCM) menjadi penting bagi perusahaan kelapa sawit, seiring dengan semakin meningkatnya persaingan usaha dan sejajarnya posisi pemasok dan pabrik kelapa sawit sebagai mitra. Penelitian ini bertujuan memetakan pola rantai pasok kelapa sawit di wilayah pantai barat Aceh, menganalisis kinerja pemangku kepentingan, dan menganalisis faktor yang mempengaruhi kinerja pemangku kepentingan di wilayah ini. Penelitian ini menggunakan metode survey dengan teknik pengumpulan data melalui wawancara dan diskusi kelompok terfokus. Hasil penelitian menunjukkan bahwa: (1) ada 3 pola rantai pasok yang menentukan aliran tandan buah segar ke pabrik kelapa sawit; (2) peran pemangku kepentingan dalam rantai pasok kelapa sawit di wilayah ini sangat menentukan volume pasokan, keuntungan, dan nilai tambah yang terbentuk, dan (3) faktor yang berpengaruh terhadap kinerja pemangku kepentingan dan peningkatan keunggulan kompetitif adalah produktivitas kebun kelapa sawit, alokasi biaya investasi dan operasi, kapasitas PKS dan rendemen CPO.

Kata Kunci: Rantai Pasok, Kelapa Sawit, Daya Saing.

\section{PENDAHULUAN}

Pengembangan kelapa sawit di Aceh merupakan kegiatan pemanfaatan sumberdaya lokal yang potensial. Hal ini didukung oleh berbagai faktor, seperti kesesuaian keadaan agroklimat dan ketersediaan sumberdaya lahan yang sesuai. Sub-sektor perkebunan khususnya kelapa sawit dalam rantai aktivitas terbagi menjadi dua bagian, hulu dan hilir. Aktivitas hulu meliputi kegiatan perkebunan, pemasaran TBS (tandan buah segar) dan 
infrastruktur agroindustri, sedangkan aktivitas hilir meliputi pabrik pengolahan kelapa sawit (PKS), stok minyak sawit mentah (crude palm oil, CPO), kernel (inti sawit) dan kegiatan ekspor. Aktivitas hulu menghasilkan banyak kegiatan lain sebagai akibat dari rantai pasokan yang lebih panjang dari sektor hilir dan beragamnya jenis produk yang ditangani. Produk-produk tersebut adalah CPO dan kernel.

Kabupaten Aceh Barat dan Nagan Raya adalah kabupaten yang memiliki perkembangan areal kelapa sawit yang sangat signifikan. Tingginya pertumbuhan kelapa sawit di dua kabupaten yang dimiliki oleh swasta dan perkebunan rakyat selama beberapa tahun terakhir. Berdasarkan data Badan Pusat Statisik (2014), pertumbuhan areal kelapa sawit Kabupaten Aceh Barat dalam kurun waktu 2007-2013 mengalami peningkatan luas areal sebesar 77,02\%, begitu juga Kabupaten Nagan Raya terjadi peningkatan luas areal yaitu sebesar $60,66 \%$.

Penerapan manajemen rantai pasok (Supply Chain Management, SCM) menjadi penting bagi perusahaan, seiring dengan semakin meningkatnya persaingan usaha dan sejajarnya posisi pemasok dan konsumen sebagai mitra. SCM adalah pendekatan terpadu berorientasi proses untuk menyediakan, memproduksi, mengirim produk serta jasa kepada konsumen (Pujawan dan Mahendrawathi, 2003). Cakupan SCM meliputi seluruh proses manajerial, informasi, dan aliran dana. Dalam SCM setiap perusahaan bertindak sebagai pemasok sekaligus pelanggan suatu rantai pasokan. Proses pemenuhan kebutuhan pelanggan dalam rantai pasokan adalah suatu mata rantai penambahan nilai yang tidak hanya berhenti di satu perusahaan, tetapi mencakup seluruh perusahaan yang menjadi anggota rantai pasokan. Keberhasilan tidak hanya ditentukan oleh kinerja perusahaan itu sendiri, tetapi ditentukan oleh kinerja keseluruhan rantai.

SCM adalah pengintegrasian dalam aktivitas manajemen rantai pasokan, yang mencangkup hubungan kerjasama organisasi, proses bisnis, dan informasi untuk menciptakan nilai guna produk. Aktivitas organisasi tersebut akan menjadi keunggulan kompetitif berkelanjutan bagi organisasi dalam rantai pasokan. Aktivitas organisasi dalam rantai pasokan seperti terlihat pada Gambar 1 memiliki dua model saluran utama, yaitu saluran langsung dan saluran tidak langsung. Kedua model saluran ini, aktivitas dimulai dari produsen hingga konsumen, pada saluran langsung aliran hanya melibatkan dua organisasi yaitu produsen dan konsumen.
Dilain pihak saluran tidak langsung melibatkan organisasi lain antara produsen dan konsumen, adanya organisasi diatas akan memberikan nilai tambah bagi produk ataupun terjadinya aktivitas yang spesifik dalam kegiatan distribusi.

Konsep manajemen rantai pasokan memperlihatkan adanya proses ketergantungan antara berbagai perusahaan yang terkait di dalam sebuah sistem bisnis. Semakin banyak perusahaan yang terlibat dalam rantai tersebut maka akan semakin kompleks strategi pengelolaan yang dibangun sehingga akan memerlukan manajemen terhadap informasi dari setiap mitra organisasi. Dengan demikian diperlukan pula sebuah sistem terpadu yang bertugas dalam pengumpulan, pengolahan, penyimpanan, dan penyebarluasan informasi kepada setiap mitra usaha tersebut (Indrajit dan Djokopranoto, 2003).

Basu (2002) mengungkapkan bahwa terdapaat pendekatan unik pada SCM dalam peramalan kolaboratif untuk kebutuhan perencanaan, peramalan, dan adopsi perlengkapan, perbaikan hasil yang substansial, pengoptimalan persediaan, dan peningkatan penerimaan. Sementara Cruz (2011) menyatakan bahwa ada hubungan yang kuat nilai-tambah dan produktivitas kebun. Parham (2011) menambahkan bahwa ada faktor penting yang menentukan besarnya produktivitas.

Sumarwan dkk (2012) menyatakan bahwa komitmen dan kepercayaan adalah dua aspek dominan yang mendasari munculnya kerjasama, daya saing serta jaminan keuntungan finansial. Solikhin et al. (2012) mengemukakan bahwa masalah yang paling penting adalah faktor keuangan pada pembiayaan pasokan TBS yang melibatkan kelompok tani dan sangat menentukan kinerja rantai pasokan TBS dan daya saing kelapa sawit.

Penelitian ini mempunyai dua tujuan. Pertama, tujuannya menganalisis nilai tambah dalam sistem rantai pasok TBS kelapa sawit di Kabupaten Nagan Raya dan Kabupaten Aceh Barat. Kedua, tujuannya menganalisis faktor-faktor yang berpengaruh terhadap kinerja dan peningkatan keunggulan kompetitif bagi perkebunan kelapa sawit di Kabupaten Nagan Raya dan Kabupaten Aceh Barat.

\section{METODE PENELITIAN}

Penelitian ini dilakukan di Kabupaten Nagan Raya dan Kabupaten Aceh Barat. Pemilihan lokasi dilakukan secara sengaja (purposive) dengan pertimbangan bahwa Kabupaten tersebut merupakan daerah sentra kelapa 
sawit di pantai Barat Aceh. Objek dalam penelitian ini adalah pelaku rantai pasok komoditi kelapa sawit mulai dari petani kelapa sawit, pedagang dan pabrik PKS yang ada di kedua kabupaten tersebut. Ruang lingkup penelitian ini merupakan serangkaian kegiatan rantai pasok dan daya saing.

Metode yang digunakan dalam pengambilan contoh dilakukan secara sengaja. Sampel diambil secara proposional dari dua kabupaten, masing-masing 5 (lima) Satuan Pengumpul (SP), tiga orang dari masing-masing Satuan Kerja Pemerintah Kabupaten (SKPK) yang memahami sistem pemasaran TBS (Bapppeda, Disbun) serta delapan orang dari pelaku usaha dan faktor pendukung di dua kabupaten tersebut (petani skala besar, dan pedagang pengumpul desa).

Analisis yang digunakan adalah analisis kuantitatif dan kualitatif yang diawali dengan penyusunan matrik semua indikator, yaitu luas panen, produksi, harga jual petani, harga jual SP dan pendapatan petani kelapa sawit. Indikator kinerja lembaga yang terlibat dalam pemasaran TBS terdiri dari volume transaksi, biaya pengumpulan, biaya pemasaran dan profit margin yang diperoleh. Selanjutnya analisis nilai tambah pada masing-masing tahapan pasokan dilakukan dengan model nilai tambah (Value Added) yang merupakan fungsi dari tingkat kesulitan aksesibelitas (A), biaya produksi(C) dan harga beli TBS $(P)$, dengan formula sebagai berikut : $V_{c}=f\left(A_{c}\right.$. $\mathrm{C}_{\mathrm{c}} \cdot \mathrm{P}_{\mathrm{c}}$. Untuk mengukur koefisien manajemen rantai pasok dianalisis dengan persamaan eksponensial berikut : $\mathrm{V}_{\mathrm{c}}=\mathrm{A}_{\mathrm{c}}{ }^{\mathrm{a} o} \cdot \mathrm{C}_{\mathrm{c}}^{\mathrm{a} 1} \cdot \mathrm{P}_{\mathrm{c}}^{\mathrm{a} 2} \mathrm{Y}$.

\section{HASIL DAN PEMBAHASAN}

PKS di dua Kabupaten Aceh Barat dan Nagan Raya sebanyak 8 unit dengan kapasitas terpasang sebesar 45 ton per jam. Akan tetapi kapasitas kerja PKS ini dibatasi sampai dengan 30 ton per jam. Seperti yang telah dijelaskan di atas bahwa rantai pasok kelapa sawit adalah jaringan unit usaha yang saling bekerjasama untuk menghimpun TBS dan mengirimkannya ke PKS pelanggan di 2 kabupaten ini. Sedangkan manajemen rantai pasok SCM adalah keterpaduan dari perencanaan, koordinasi dan kendali seluruh proses dan aktivitas bisnis dalam rantai pasok untuk menghantarkan nilai maksimal kepada konsumen dengan biaya termurah sebagai keseluruhan yang memenuhi kebutuhan kepuasaan para pihak yang berkepentingan dalam rantai pasok tersebut.
Para pengusaha PKS menyadari bahwa keunggulan daya saing CPO dan Kernel perlu didukung oleh aliran TBS dari petani ke PKS secara efisien dan efektif. Sebagai pendukung kelancaran arus TBS maka harus terjadi juga aliran informasi yang terkait diantara komponen yang terlibat dalam rantai pasok. Tahapan yang harus dilalui oleh TBS mulai dari pengumpulan TBS oleh agen-agen pengumpul di desa, mengangkut ke SP dan atau langsung membawa ke PKS. Dilihat dari aliran ini maka rantai pasok TBS sangat sederhana.

Sistem Rantai Pasok TBS untuk PKS yang ada dapat digambarkan dari dua sudut, yaitu: (a) pasokan TBS dan (b) hasil PKS. Tandan buah sawit (TBS) menjadi produksi bagi perkebunan kelapa sawit dan menjadi bahan baku dalam industri PKS. Bahan baku PKS ini diperoleh dari kebun sendiri dan dari perkebunan rakyat di sekitarnya, sampai dengan tahun 2013 enam PKS yang telah beroperasi mengandalkan bahan baku dari kebun sendiri antara 30 sampai dengan $60 \%$. Dengan kapasitas produksi 30 ton TBS per jam, beberapa PKS membeli TBS dari perkebunan rakyat di sekitarnya melalui SP yang telah dibentuk. Hasil inventarisasi SP enam PKS yang telah beroperasi menunjukkan terdapat 21 SP yang telah mengantongi kontrak pengadaan TBS di Kabupaten Nagan Raya, dan 9 SP di Kabupaten Aceh Barat. Dari 30 SP ini terdapat 12 SP yang aktif, sedangkan 18 lainnya masih mengandalkan hasil pengumpulan agen TBS di sentra-sentra produksi.

Dalam sistem rantai pasok TBS terdapat beberapa pihak yang terlibat antara lain: (a) Agen pengumpul desa, (b) SP dan (c) PKS. Agen pengumpul di desa-desa sentra produksi membeli TBS petani kelapa sawit dengan harga yang sangat bervariasi. SP membeli TBS dari agen pengumpul desa dengan harga yang telah disepakati dengan petani. SP ini memiliki kuota pasokan pada PKS masing-masing dengan beberapa kewajiban yang harus dipenuhi. Pada rantai pasok TBS kelapa sawit yang terdapat di Kabupaten Nagan Raya dan Kabupaten Aceh Barat terdiri dari 3 macam, yaitu:

a. Sistem Pasok I : Petani skala besar ke PKS

b. Sistem Pasok II : Petani skala kecil ke Satuan Pengumpul dan ke PKS

c. Sistem Pasok III : Petani kecil ke Agen Desa ke Satuan Pengumpul dan ke PKS 


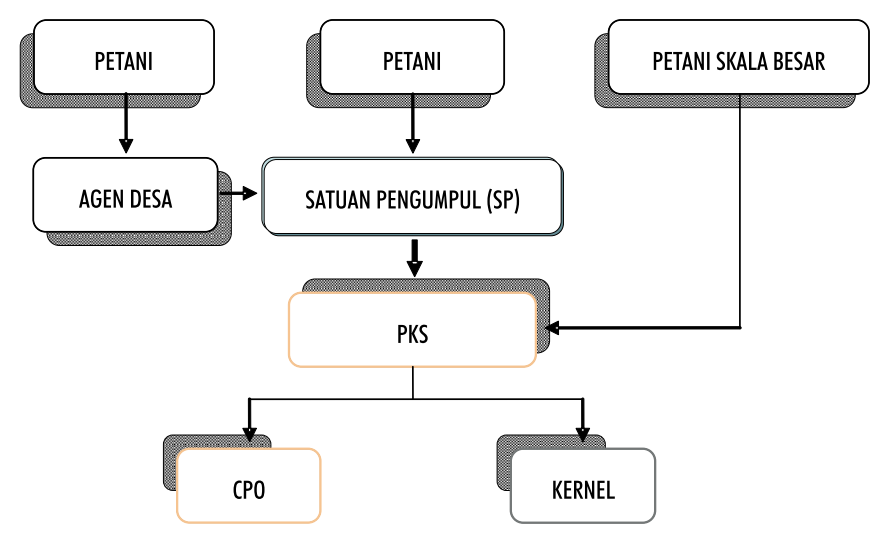

GAMBAR I. SISTEM PASOK TBS UNTUK PKS DI PANTAI BARAT TAHUN 2014

Dalam teori rantai pasok bahwa ukuran kinerja dan peran masing-masing pelaku ditentukan oleh empat hal, yakni: Persediaan, transportasi, fasilitas dan informasi. Kinerja persediaan pada pedagang pengumpul desa sangat tergantung pada ukuran produksi TBS yang dikelola melalui kelompok petani yang menjadi pemasok. Hal ini terukur dari volume pasokan dan kontinuitas produksi, pedagang pengumpul desa memiliki sistem transportasi mulai dari kendaraan langsir dan truk yang digunakan ke PKS. Fasilitas yang dimiliki oleh pedagang pengumpul desa dalam bentuk gudang penampungan dan perangkat pasokan seperti timbangan dan alat menentukan kematangan TBS. Pada umumnya pedagang pengumpul desa sebagai sistem pertama dalam rantai pasok TBS belum memiliki informasi yang transparan dari PKS, melainkan ditentukan oleh SP yang menjamin pasokan TBS tersebut. Dengan demikian kelemahan pedagang pengumpul desa adalah akses informasi volume dan harga penetapan TBS dari PKS tersebut.

Berbeda halnya dengan kinerja petani skala besar yang telah memiliki akses langsung ke PKS, sehingga informasi volume dan harga TBS diterima langsung dari PKS tersebut. Petani skala besar ini juga telah melengkapi fasilitas pasokan dan sistem transportasi yang efektif. Oleh karena itu kinerja petani ini lebih baik dibandingkan dengan petani skala kecil dan pedagang pengumpul desa.

Volume pembelian 5 unit PKS dapat disimulasikan berdasarkan jumlah jam kerja per hari dan hari kerja per tahun. Apabila kapasitas kerja PKS ini dibatasi sampai dengan 30 ton per jam dan jam kerja adalah 20 jam per hari serta hari kerja adalah 300 hari per tahun maka volume pembelian delapan unit PKS ini adalah 1.440.000 ton per tahun. Akan tetapi karena semua PKS tidak bekerja dalam kapasitas penuh maka volume pembelian TBS di wilayah ini lebih kecil. Dari lima PKS sampel yang diteliti total kebutuhan TBS selama tiga kwartal yang dianalisis adalah 355.920 ton. Volume pembelian juga bervariasi diantara PKS dan periode pembelian. PKS tersebut juga tidak melakukan pembatasan volume pembelian diantara saluran pemasaran, sehingga terdapat perimbangan volume pembelian diantara tiga sistem pasok tersebut.

Pada penelitian ini nilai tambah diartikan sebagai manfaat yang dapat diambil oleh PKS dari bahan baku CPO dan kernel tersebut. PKS sebagai pembeli akan mempertimbangkan nilai manfaat terhadap TBS tersebut berdasarkan harga atau biaya-biaya operasional dan investasi yang harus dikeluarkannya ditambah biaya untuk mendapatkan bahan baku tersebut, dibandingkan dengan manfaat atau keuntungan yang akan didapatkannya dari bahan baku tersebut setelah diproses menjadi CPO dan kernel. Semakin tinggi selisih manfaat dengan biaya-biaya yang dikeluarkannya maka akan semakin semakin tinggi nilai tambahnya, akan semakin rela PKS membeli TBS tersebut. Sebaliknya bila selisih itu semakin sedikit maka PKS akan semakin kurang rela membelinya. Dengan demikian maka dalam proses negosiasi pengusaha PKS akan cenderung untuk selalu mencari petani atau SP penjual yang akan memberikan nilai tambah yang paling tinggi. Para manajer PKS telah melakukan pembinaan terhadap SP yang memiliki kuota pasokan TBS. Akan tetapi beberapa SP juga memiliki hubungan yang khusus dengan agen pengumpul di desa sentra produksi dan petani kelapa sawit yang memiliki skala usaha yang besar. Pasokan TBS disesuaikan dengan kapasitas kerja PKS dan kondisi SP masing-masing.

Terdapat beberapa alasan terjalinnya kemitraan di antara SP dengan petani dan agen pengumpul di desa, antara lain: (a) pembagian peran, (b) distribusi nilai tambah, dan (c) penguasaan sentra produksi. Hasil penelitiaan menunjukkan nilai tambah yang dibagi berdasarkan peran masing-masing, nilai tambah tertinggi diperoleh PKS yang mengolah TBS menjadi CPO dan kernel, seperti yang ditunjukkan pada Tabel 1 berikut ini.

Jumlah pasokan TBS paling ditentukan oleh produksi dan produktivitas petani. Semakin besar produksi kelapa sawit maka akan semakin besar nilai tambah yang diperoleh petani dalam sistem nilai TBS. Pada Tabel 1 terlihat perbedaan nilai tambah yang diperoleh agen pengumpul desa dan SP di Kabupaten Aceh Barat dan 
TABEL I. NILAI TAMBAH PELAKU PADA SISTEM RANTAI PASOK TBS DI PANTAI BARAT ACEH

\begin{tabular}{llll}
\hline \multirow{2}{*}{ Pelaku Usaha } & \multicolumn{2}{l}{ Nilai Tambah (\%) } & \multirow{2}{*}{ Rerata } \\
& Aceh Barat & Nagan Raya & \\
\hline Petani & 79,7 & 79,8 & 79,8 \\
Agen Pengumpul Desa & 11,7 & 8,9 & 10,3 \\
Satuan Pengumpul (SP) & 4,8 & 11,5 & 8,1 \\
Pabrik Kelapa Sawit (PKS) & 56,7 & 56,7 & 56,7 \\
\hline
\end{tabular}

Nagan Raya. Untuk agen pengumpul desa di Kabupaten Aceh Barat nilai tambah yang diperoleh lebih besar dari agen pengumpul di wilayah Nagan Raya. Hal ini disebabkan perbedaan margin yang dipotong dari setiap harga TBS, padahal biaya pengumpulan TBS hampir sama di dua wilayah kabupaten tersebut. Akibatnya nilai tambah yang diperoleh SP di wilayah Kabupaten Aceh Barat lebih kecil dari SP yang beroperasi di Kabupaten Nagan Raya.Duaunit PKS yang beroperasi di Kabupaten Aceh Barat telah mengalokasikan nilai tambah TBS sesuai dengan korbanan pada masing-masing pelaku usaha, walaupun nilai tambah yang diperoleh PKS masing sangat dominan.

Persamaan regresi yang menggambarkan peran masing-masing pelaku adalah sebagai berikut: $\mathrm{V}_{\mathrm{c}}=83,557$ $\mathrm{A}_{c}{ }^{7,921} \cdot \mathrm{C}_{c}^{-2,989} \cdot \mathrm{P}_{c}^{-3,138}$. Koefisien determinasi $\mathrm{R}^{2}=0,943$ atau 94,3\% yang artinya bahwa bobot kesulitan dalam proses produksi yang diperankan oleh masing-masing pihak yang terlibat dalam sistem rantai pasok TBS, biaya yang ditanggung dan harga TBS sangat menentukan nilai tambah sistem rantai pasok. Dengan kata lain nilai tambah pada sistem pasok 94,3\% ditentukan oleh bobot peran, kontribusi biaya produksi dan harga TBS pada masing-masing pelaku pada sistem rantai pasok. Sedangkan 5,7\% lain ditentukan oleh sistem eksternal yang tidak masuk dalam model analisis.

Kebenaran model jugaditentukanoleh F hitung yang diperoleh 110,512 Pengujian secara serempak menunjukkan $\mathrm{F}_{\text {hitung }}=110,512$ sedangkan $\mathrm{F}_{\text {tabela }=0,05}=$ 19,44; dan $\mathrm{F}_{\text {tabela }=0,01}=99,45$. Artinya ada pengaruh antara peran pelaku usaha dalam rantai pasokan kelapa sawit dengan kinerja dan keunggulan kompetitif dari sektor usaha perkebunan kelapa sawit di Kabupaten Nagan Raya dan Kabupaten Aceh Barat. Secara parsial tiga variabel (bobot peran pelaku, kontribusi biaya dalam sistem dan harga TBS) berpengaruh nyata terhadap nilai tambah sistem rantai pasok TBS. Pengujian secara parsial menunjukkan $t_{\text {cari }}=15,859,-16,271$ dan $-16,109$ sedangkan $\mathrm{t}_{\text {tabel } \mathrm{a}=0,05}=1,725$; dan $\mathrm{t}_{\text {tabel } \mathrm{a}=0,01}=2,528$. Artinya ketiga variabel tersebut mempengaruhi nilai tambah.

Setiap anggota dari rantai pasok dimodelkan sebagai suatu agen yang mandiri dan memiliki kemampuan membuat keputusan sendiri berdasarkan informasi lingkungan yang tersedia. Dengan demikian maka fasilitas produksi diwakili oleh Agen desa, SP dan PKS, yang merupakan replika dari keputusan-keputusan yang dibuat oleh seorang manager pabrik, berdasarkan arus barang yang mengalir dan keluar masuk pada PKS dan informasi strategis yang dibuat perusahaan (misalnya kualitas TBS, PKS pesaing, dan ongkos angkut). Pedagang pemegang SP diwakili oleh agen pengumpul di desa-desa sentra produksi. Perilaku para pedagang ini yang membuat keputusan membeli dan menjual TBS berdasarkan harga dan permintaan PKS. Demikian juga PKS yang merupakan replika perilakunya dalam memutuskan mengenai membeli TBS atas dasar pasar CPO dan kernel. Oleh karena itu volume pembelian TBS oleh PKS merupakan fungsi keputusan SP yang menjadi pemegang kuota.

Produk CPO Indonesia dapat menjadi sebagai salah satu komoditi berdayasaing saing tinggi dalam perdagangan ekspor. Kuota ekspor yang besar dari beberapa negara didorong karena minat pengusaha negara tersebut semakin tinggi untuk mengimpor $\mathrm{CPO}$ dari Indonesia. Dalam implementasi pengaturan jatah kuota oleh beberapa negara misalnya, telah ditetapkan aturan bahwa ekspor di luar kuota dikenakan bea masuk (BM) lebih dari 50\%. Sedangkan CPO berkuota hanya dikenakan bea masuk untuk CPO sebesar 9\%. Dengan aturan seperti itu, sudah pasti importir beberapa negara dan eksportir nasional tidak mau langsung melakukan transaksi pengiriman komoditas tersebut, tetapi menunggu lebih dahulu rekomendasi penjatahan. Oleh karena itu, dikhawatirkan pengaturan kuota berpotensi 
menghambat kegiatan ekspor CPO Indonesia. Begitu pula halnya dengan bea masuk yang tinggi tersebut. Hasil wawancara dengan pengusaha PKS, juga ada beberapa negara lain juga memberikan kuota ekspor CPO kepada negara agensi seperti Singapura dan Malaysia. Hambatan kuota dan bea masuk yang dihadapi eksportir CPO Indonesia selama ini akan berakhir dengan dimulainya MEA 2015.

\section{KESIMPULAN}

Pada sistem rantai pasok kelapa sawit di Kabupaten Nagan Raya dan Kabupaten Aceh Barat terdapat tiga sistem yang khas menentukan aliran TBS ke lima PKS utama di Wilayah Pantai Barat Aceh. Kekhasan sistem rantai pasok ditentukan oleh besarnya peran masingmasing dalam rantai pasok TBS.

Peran stakeholder dalam sistem rantai pasok kelapa sawit di Kabupaten Nagan Raya dan Kabupaten Aceh Barat sangat menentukan volume pasokan, keuntungan, dan nilai tambah yang terbentuk. Peran agen pengumpul desa paling dominan terhadap volume pasokan TBS pada lima PKS utama.

Faktor yang berpengaruh terhadap kinerja pemangku kepentingan dan peningkatan daya saing bagi perkebunan kelapa sawit di Kabupaten Nagan Raya dan Kabupaten Aceh Barat adalah bobot peran pelaku, kontribusi biaya dan harga jual. Harga TBS berpengaruh nyata terhadap nilai tambah sistem rantai pasok TBS. Keuntungan pelaku yang terlibat dalam sistem rantai pasok ditentukan oleh efisiensi biaya, dan volume pasokan TBS.

Untuk meningkatkan kinerja sistem rantai pasok kelapa sawit di pantai barat Aceh perlu dilakukan penataan wilayah pasokan sesuai dengan kedudukan operasi PKS yang bersangkutan.

UCAPAN TERIMA KASIH

Peneliti mengucapkan terima kasih kepada Lembaga Penelitian Unsyiah atas bantuan dana Hibah Pascasarjana Unsyiah Tahun 2014.

\section{DAFTAR PUSTAKA}

Badan Pusat Statistik. 2014. Aceh dalam Angka 2014. Badan Pusat Statistik Aceh. Banda Aceh

Basu, R. 2002. New Criteria of Performance Management: a Transition From Enterprise to Collaborative Supply Chain. Measuring Business Exellence. Volume 5(4)

Cruz, EA. 2011.Productivity Assessment Survey Featuring

\section{Value-added Productivity}

Measurement. APO Trainingcourse on the Development ofProductivity Practitioners. Manila.

Indrajit, R.E., Djokopranoto, R. 2003. Konsep Manajemen

Supply Chain: Cara baru Memandang Mata Rantai

Penyediaan Barang. Grasindo.Jakarta.

Parham, D. 2011. Definition, Importance And Determinants of Productivity. Workshop for the Public Sector Linkages Program.University of Adelaide. Adelaide

Pujawan, I.N., Mahendrawathi, E.R. 2010.SupplyChain Management. Penerbit GunaWidya. Surabaya

Solikhin, Anas M. Fauzi, Hadi K. Purwadaria. 2012.Analysis of Oil Palm Sustainable Replanting Models, A Case at PT Agrowiyana, Tunggul Ulu, Tanjung Jabung Barat, Jambi.Jurnal Manajemen \&Agribisnis, MB. IPB, Bogor, Vol. 9. No. 3

Sumarwan,U. Agus Maulana,Muchlis Ahmady,Budi Suharjo. 2012. Key Success Values in Relationship Marketing of Agriculture Products, Jurnal Manajemen \&Agribisnis, MB. IPB, Bogor, Vol. 9. No. 2 